\title{
Učestalost seksualnih disfunkcija u bolesnika s depresivnim poremećajem liječenih antidepresivima iz različitih skupina
}

1 Marijana Hodak Ivanišević

1 Suzana Uzun

1 Oliver Kozumplik

1,2 Ninoslav Mimica

1 Klinika za psihijatriju Vrapče, Bolnička cesta 32, 10090 Zagreb

2 Medicinski fakultet Sveučilišta u Zagrebu, Šalata 3B, 10000 Zagreb

\section{Sažetak}

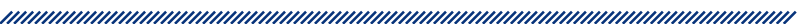

Cilj: Analizirati učestalost seksualnih disfunkcija kod bolesnika s dijagnozom depresivnog poremećaja koji u terapiji uzimaju antidepresive iz različitih skupina.

Ispitanici i metode: U ispitivanju je sudjelovalo 50 bolesnika s dijagnozom depresivnog poremećaja koji su bili na bolničkom ili ambulantnom liječenju u Klinici za psihijatriju Vrapče, Zavodu za biologijsku psihijatriju. Podaci su dobiveni u razgovoru s bolesnicima te uvidom u medicinsku dokumentaciju, a za evaluaciju seksualnog funkcioniranja ispitanika primijenjena je Skala seksualnog funkcioniranja. Prije uključenja u istraživanje ispitanici su dobili informacije o istraživanju i potpisali informirani pristanak za sudjelovanje u ovom istraživanju. Razlike u opaženim vrijednostima po spolu i dobnim skupinama testirane su Fisherovim testom. Rezultati su analizirani s pomoću statističkog programa SPSS, verzija 13 (SPSS Inc, Chicago, IL, SAD). Rezultati su tumačeni uz prihvatljivu razinu značajnosti $\mathrm{P}<0,05$.
Rezultati i zaključak: Rezultati ovog istraživanja pokazali su višu učestalost javljanja seksualnih disfunkcija u bolesnika s depresivnim poremećajem koji u terapiji uzimaju antidepresive iz skupine SIPPS-a, u usporedbi s pacijentima koji su uzimali antidepresive iz drugih skupina, što je u skladu s rezultatima iz literature. Rezultati istraživanja ukazuju na važnost redovitog praćenja seksualnih disfunkcija tijekom terapije antidepresivima u bolesnika s depresivnim poremećajem.

Ključne riječi: antidepresivi; depresivni poremećaj; seksualne nuspojave; tretman

Datum primitka: 23.11.2015.

Datum prihvaćanja: 30.03.2016.

Adresa za dopisivanje:

Doc. dr. sc. Suzana Uzun

Klinika za psihijatriju Vrapče

Bolnička cesta 32, 10090 Zagreb

E-pošta: suzana.uzun@bolnica-vrapce.hr

Tel.: +38513780666

Faks: +38513780622

\section{Uvod}

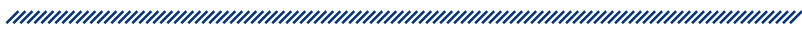

Poznavanje nuspojava i njihovih osnovnih značajki jedan je od uvjeta za racionalnu primjenu lijekova. Nuspojave lijeka uvelike pridonose kvaliteti života, obiteljskom i radnom funkcioniranju. Znatno utječu na 
suradljivost bolesnika te njegovo prihvaćanje terapijskog procesa ${ }^{1}$.

Učestalost depresivnih poremećaja u općoj je populaciji 3,6 do 6,8\%, a prema nekim podacima prevalencija velikog depresivnog poremećaja u zapadnim zemljama iznosi oko 6 do $12 \%$, a doživotni je rizik obolijevanja od 27 do $37 \%$. Svaka peta žena i svaki deseti muškarac tijekom života dožive barem jednu ozbiljnu depresivnu epizodu. Gotovo $75 \%$ depresivnih bolesnika pomišlja na suicid, 10 do $15 \%$ ga i izvršava, a posebno zabrinjava visoka stopa samoubojstava mladih ${ }^{2,3}$.

Antidepresivi su skupina lijekova vrlo različitog mehanizma djelovanja i strukture sa zajedničkim svojstvom da kod visokog postotka depresivnih osoba dovode do djelomičnog ili potpunog povlačenja depresivnih simptoma i znakova².

Seksualne smetnje obilježene su poremećajima spolne želje i psihofiziološkim promjenama koje obilježavaju ciklus spolnog odgovora i uzrokuju znatne smetnje ${ }^{1}$.

Istraživanja koja su se oslanjala isključivo na spontane izjave bolesnika bilježila su zamjetno manju učestalost seksualnih nuspojava od istraživanja u kojima su primijenjeni strukturirani intervjui odnosno upitnici ${ }^{4,5}$.

Razgovorom o seksualnom ponašanju liječnik može pridonijeti preventivi seksualnih poremećaja, jer može dati točne obavijesti o seksualnome zdravlju, nasuprot mitova ili predrasuda koje mogu pridonijeti seksualnim poremećajima ili smanjenoj kvaliteti seksualnog zdravlja ${ }^{6}$.

Prema rezultatima istraživanja, seksualna disfunkcija predstavlja problem za osobu koja se liječi zbog depresije, a uzrok joj mogu biti depresivni simptomi ili nuspojava antidepresiva. Selektivni inhibitori ponovne pohrane serotonina (SIPSS) predstavljaju skupinu antidepresiva koji su često povezani sa seksualnom disfunkcijom, čak i nakon poboljšanja depresivnih simptoma?

Depresija i seksualna disfunkcija imaju dvosmjernu povezanost. Kada se dijagnosticira depresivni poremećaj na početku treba procijeniti seksualno funkcioniranje odgovarajućim ocjenskim skalama. Ako se seksualne nuspojave razviju tijekom tretmana antidepresivima, terapijske mogućnosti uključuju čekanje na spontani oporavak, snižavanje doze lijeka, prebacivanje na drugi lijek ili dodavanje drugog lijeka ili dodatnog lijeka.

Prema rezultatima istraživanja, bupropion i novi antidepresivi pokazuju povoljniji profil seksualnih disfunkcija u usporedbi s drugim antidepresivima, posebno SIPSS-a i inhibitora ponovne pohrane serotonina i no- radrenalina (SNRI). Bupropion, mirtazapin i buspiron istraživani su kao dodatni lijekovi ili supstitucijski lijekovi u tretmanu seksualnih disfunkcija uzrokovanih antidepresivima $^{8}$.

SIPPS-i se često primjenjuju u tretmanu bolesnika s velikim depresivnim poremećajem. Ipak nuspojave SIPPSa na seksualnu funkciju česte su u tretmanu depresivnih bolesnika. Postoje proturječni podaci u izvještajima o učestalosti seksualnih disfunkcija koje izazivaju SIPPSi. S druge strane ima manje podataka o seksualnim disfunkcijama s 5-HT2 antagonistima/inhibitorima ponovne pohrane serotonina (SARI) ${ }^{9}$.

Khazaie i suradnici u istraživanju su ocjenjivali seksualnu disfunkciju u bolesnika s depresivnim poremećajem koji su u terapiji uzimali fluoksetin, sertralin i trazodon. Kao rezultati tog istraživanja dobivene su razlike u učestalosti javljanja seksualne disfunkcije u bolesnika koji u terapiji uzimaju različite antidepresive. $U$ usporedbi s fluoksetinom i sertralinom, trazodon je povezan s manje seksualnih disfunkcija. Fluoksetin je povezan s više seksualnih disfunkcija nego sertralin. Potrebna su daljnja istraživanja na tom području9 Seksualne disfunkcije nastale tijekom terapije SIPPSima nalazimo u $30 \%$ do $50 \%$ bolesnika. Dokazano je da fluvoksamin dovodi do povišenja koncentracije serumskog prolaktina, a slučajevi galaktoreje zabilježeni su tijekom terapije klomipraminom, amoksapinom i fluoksetinom $^{1,10}$. Podaci pokazuju akutno i prolazno povišenje koncentracije prolaktina u plazmi tijekom liječenja moklobemidom ${ }^{10}$. Tijekom terapije fluoksetinom zabilježeni su slučajevi hiperprolaktinemije i galaktoreje te smanjenja libida.

U kliničkoj studiji s paroksetinom zamijećen je poremećaj ejakulatorne funkcije, ali postoje i radovi koji opisuju učinak paroksetina u tretmanu prijevremene ejakulacije $^{1}$. Klinička istraživanja pokazala su da se seksualne disfunkcije u obliku poremećaja orgazma, ejakulacije i erektilne funkcije češće javljaju u terapiji venlafaksinom i klomipraminom u usporedbi s nefazodonom, mirtazapinom, bupropionom i moklobemidom ${ }^{1}$. U terapiji sertralinom može se javiti poremećaj u obliku odgođene ejakulacije ${ }^{10}$. Prijapizam je zabilježen pri terapiji citalopramom, nefazodonom, trazodonom i imipraminom ${ }^{1}$.

Biokemijski mehanizmi za koje se smatra da su ključni za izazivanje seksualnih nuspojava uključuju povišeni serotonin, osobito preko receptora $5-\mathrm{HT}_{2}$ i $5-\mathrm{HT}_{3}$; sniženi dopamin; blokadu kolinergičkih i alfa-1 adrenergičnih receptora te povišenje koncentracije prolaktina ${ }^{1}$. Podaci pokazuju različite i o vremenu ovisne učinke ser- 
tralina na razinu kortizola u plazmi, prolaktin i tiroidne hormone kod žena koje boluju od depresije. SIPPS-i u terapiji depresivnih bolesnika mogu izazvati poremećaj orgazma u oba spola. Tijekom terapije fluoksetinom $\mathrm{i}$ sertralinom može doći do smanjenja libida, dok terapija fluvoksaminom može dovesti do povećanja libida. Pri terapiji SIPPS-ima uočena je pojava impotencije; kliničke studije povezuju paroksetin i citalopram s ovom nuspojavom. U terapiji sertralinom može se javiti poremećaj ejakulacije u vidu odgođene ejakulacije ${ }^{1}$. Podaci pokazuju akutno i prolazno povišenje koncentracije prolaktina u plazmi tijekom liječenja moklobemidom i trazodonom. Liječenje klomipraminom, kao i imipraminom, također može dovesti do smanjenja libida. Inhibitori monoaminooksidaze (IMAO) mogu dovesti do impotencije i poremećaja ejakulacije. Reboksetin u dozama većima od $8 \mathrm{mg}$ dnevno može dovesti do impotencije. Triciklički antidepresivi (TCA) uzrokuju poremećaj erektivne i ejakulatorne funkcije ${ }^{1}$. Prijapizam je zabilježen pri terapiji trazodonom i imipraminom. Uz klomipramin i amoksapin češće se kao neželjene posljedice liječenja javljaju galaktoreja i amenoreja ${ }^{1}$.

TCA-i uzrokuju poremećaj erektivne i ejakulatorne funkcije, a rezultati kliničkih istraživanja nisu pokazali značajne razlike među pojedinim TCA-ima ${ }^{1}$.

Budući da psihofarmaci imaju vrlo veliku terapijsku širinu, teško je predvidjeti kada će se javiti neka nuspojava. Postoje velike individualne razlike u kliničkom odgovoru bolesnika, stoga je nužno opservirati bolesnika te pravovremeno uočiti pojavljenu nuspojavu te izvijestiti liječnika.

U ovom radu cilj je bio analizirati učestalost seksualnih disfunkcija kod bolesnika s dijagnozom depresivnog poremećaja koji u terapiji uzimaju antidepresive iz različitih skupina.

\section{Ispitanici i metode}

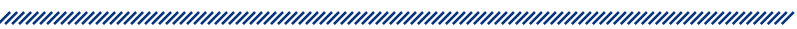

$\mathrm{U}$ ispitivanju je sudjelovalo 50 bolesnika s dijagnozom depresivnog poremećaja prema dijagnostičkim kriterijima DSM-IV³ koji su bili na bolničkom ili ambulantnom liječenju u Klinici za psihijatriju Vrapče, Zavodu za biologijsku psihijatriju. $U$ istraživanje je uključeno 36 žena i 14 muškaraca koji su u terapiji uzimali različite antidepresive i u dobi su od 27 do 55 godina. Prije uključenja u istraživanje ispitanici su dobili informacije o istraživanju i potpisali informirani pristanak za sudjelovanje u ovom istraživanju. Istraživanje je odobrilo Etičko povjerenstvo Klinike za psihijatriju Vrapče. Podaci su dobiveni u razgovoru s bolesnicima te uvidom u medicinsku dokumentaciju, a za evaluaciju seksualnog funkcioniranja ispitanika primijenjena je Skala seksualnog funkcioniranja ${ }^{1}$. Razlike u opaženim vrijednostima po spolu i dobnim skupinama testirane su Fisherovim testom. Rezultati su tumačeni uz prihvatljivu razinu značajnosti $\mathrm{P}<0,05$.

\section{Rezultati}

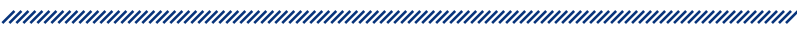

Prema rezultatima istraživanja osobe muškog spola statistički značajno više nego žene u zadnjih mjesec dana razmišljali su o seksu tri puta tjedno $(P=0,01)$ (tablica 1$)$.

\begin{tabular}{|c|c|c|c|}
\hline \multicolumn{4}{|c|}{$\begin{array}{c}\text { Tablica } 1 . \\
\text { Razmišljanje o seksu (u zadnjih mjesec dana) }\end{array}$} \\
\hline $\begin{array}{l}\text { 1. Razmišljanje o seksu } \\
\text { (u zadnjih mjesec dana): }\end{array}$ & $\begin{array}{c}\check{Z} \\
(n=36) \\
\%\end{array}$ & $\begin{array}{c}M \\
(n=13) \\
\%\end{array}$ & $\mathrm{P}$ \\
\hline a. Barem jednom dnevno & 22,22 & 53,85 & 0,076 \\
\hline b. Tri puta tjedno & 19,44 & 61,54 & $0,011^{*}$ \\
\hline c. Manje od jednom tjedno & 13,89 & 30,77 & 0,220 \\
\hline $\begin{array}{l}\text { d. Manje od jednom u dva } \\
\text { tjedna }\end{array}$ & 36,11 & 15,38 & 0,293 \\
\hline $\begin{array}{l}\text { 2. Nikada ne razmišljam o } \\
\text { seksu }\end{array}$ & 22,22 & 0,00 & 0,090 \\
\hline $\begin{array}{l}\text { 3. Smatram druge ljude } \\
\text { seksualno poželjnima }\end{array}$ & 25,00 & 46,15 & 0,178 \\
\hline $\begin{array}{l}\text { 4. Nisam imao/la želje za } \\
\text { spolnim odnosom }\end{array}$ & 41,67 & 23,08 & 0,322 \\
\hline $\begin{array}{l}\text { 5. Imao/la sam spolne } \\
\text { odnose }\end{array}$ & 52,78 & 69,23 & 0,348 \\
\hline $\begin{array}{l}\text { 6. Nisam bio/la } \\
\text { zainteresiran/a za seks }\end{array}$ & 55,56 & 38,46 & 0,345 \\
\hline $\begin{array}{l}\text { 3. Smatram druge ljude } \\
\text { seksualno poželjnima }\end{array}$ & 25,00 & 46,15 & 0,178 \\
\hline $\begin{array}{l}\text { 4. Nisam imao/la želje za } \\
\text { spolnim odnosom }\end{array}$ & 41,67 & 23,08 & 0,322 \\
\hline $\begin{array}{l}\text { 5. Imao/la sam spolne } \\
\text { odnose }\end{array}$ & 52,78 & 69,23 & 0,348 \\
\hline $\begin{array}{l}\text { 6. Nisam bio/la } \\
\text { zainteresiran/a za seks }\end{array}$ & 55,56 & 38,46 & 0,345 \\
\hline
\end{tabular}


Nema statistički značajnih razlika po spolu u tome jesu li se u zadnjih mjesec dana mogli seksualno uzbuditi, iako je razvidno da se muškarci češće lakše uzbuđuju od žena ( $46 \%$ vs. $16 \%$ ) te da kod žena, iako su bile mentalno uzbuđene, češće nije bilo fizičkih manifestacija nego kod muškaraca (58 \% vs. $23 \%$ ) (slike 1 i 2).

U zadnjih mjesec dana muškarci su u 61 \% slučajeva uvijek mogli postići erekciju ako su to željeli, u $54 \%$ slučajeva im se činilo da erekcije nisu potpune kao ranije, u $46 \%$ su slučajeva u zadnjih mjesec dana imali erekciju manje od jednom tjedno.

U žena su u zadnjih mjesec dana spolni odnosi bili otežani ili bolni zbog toga što nisu imale u potpunosti odgovarajuću tjelesnu reakciju, tjelesna reakcija na seksualnu stimulaciju sada je drugačija nego ranije i tjelesna reakcija na seksualnu stimulaciju sada je lošija nego ranije u više od $70 \%$ slučajeva.

Muškarci navode da su masturbirali manje od jednom u dva tjedna statistički više nego što to navode žene $(P=0,036)$. Statistički značajno više žena nikada ne masturbira u odnosu na muškarce $(P=0,004)$.

Muškarci statistički značajno češće od žena dožive orgazam/ejakulaciju koliko god često žele $(P=0,043)$. Kod žena je orgazam/ejakulacija bio statistički značajno drugačiji nego ranije u odnosu na muškarce $(P=0,022)$.
Muškarci statistički značajno češće od žena doživljavaju orgazam/ejakulaciju pri svakom spolnom odnosu / masturbaciji $(P<0,001)$.

U 7,7 \% je slučajeva količina ejakulata veća nego ranije, a nijedan muškaraca nije naveo da je promijenjena boja.

Osobe do 45 godina češće od osoba starijih od 45 godina razmišljaju barem jednom dnevno o seksu $(P=0,003)$.

Osobe starije od 45 godina ne mogu se uopće seksualno uzbuditi češće nego mlađe osobe ( $41 \%$ vs. $12 \%)$. Nema statistički značajnih razlika po dobi u odgovorima povezanima s postizanjem erekcije. Čak $35,0 \%$ ispitanika na SIPPS-ima, 25,0 \% ispitanika na tricikličkim antidepresivima, 33,3\% ispitanika na noradrenergičnim i 26,67 \% ispitanika na lijekovima iz skupine SNRI potvrdilo je da nije bilo zainteresirano za seks (slika 3).

Tjelesna reakcija na seksualnu stimulaciju sada je lošija nego ranije u $83 \%$ žena starijih od 45 godina te kod $50 \%$ žena u dobii do 45 godina, međutim ta razlika nije statistički značajna.

Statistički značajno više ispitanika starosne skupine više od 45 godina u odnosu na ispitanike mlađe dobne skupine navodi da nikada ne masturbira $(P=0,007)$. Razlike u ejakulaciji po dobnim skupinama nisu statistički značajne.

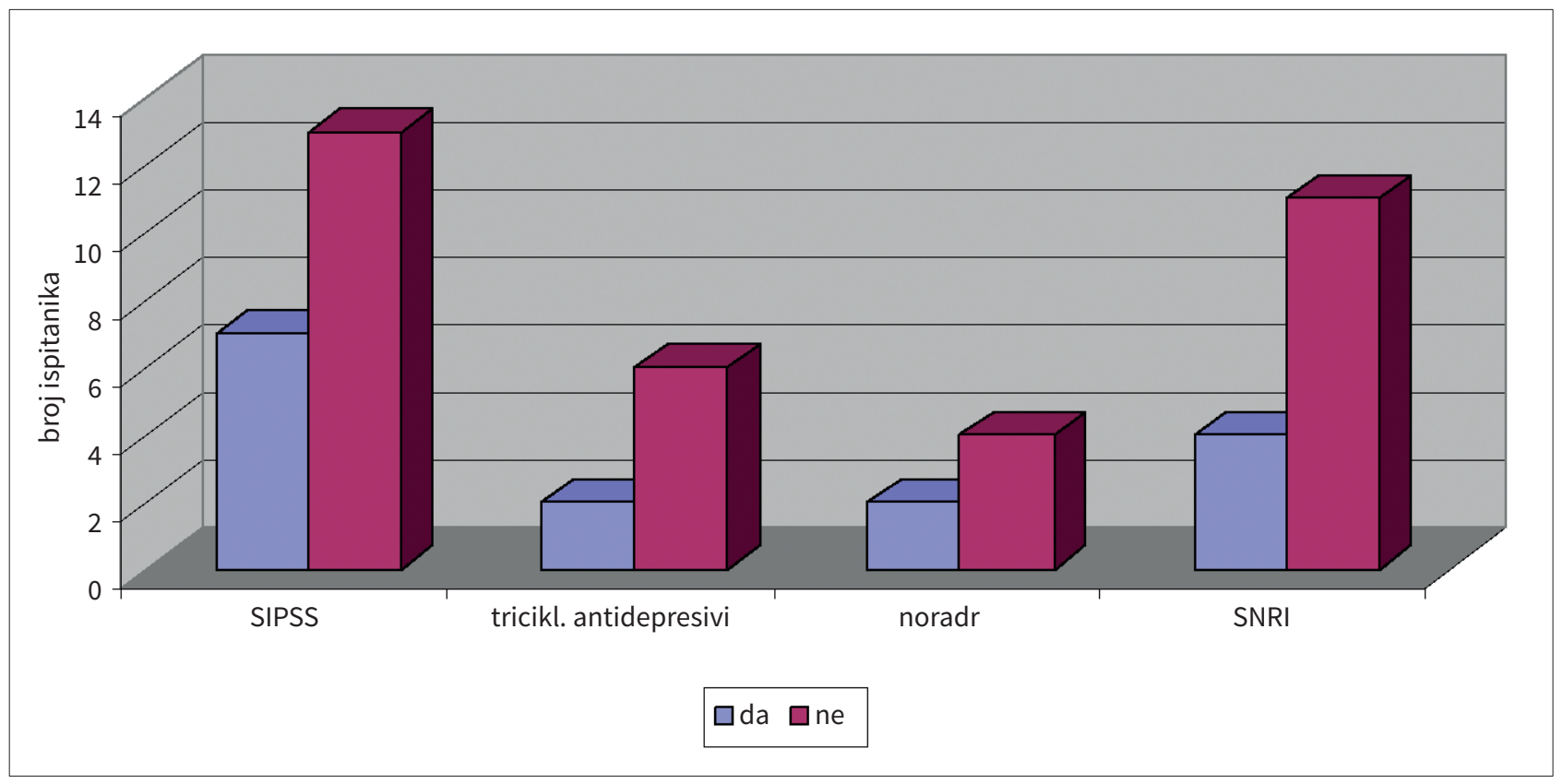

Slika 1. Odgovor bolesnika na tvrdnju „U zadnjih mjesec dana nisam se uopće mogao/la seksualno uzbuditi" u odnosu na skupinu antidepresiva koji uzimaju 
U skupini ispitanika koji u terapiji uzimaju SIPPS-e najviše je i dobivenih odgovora o razmišljanjima o seksu manje od jednom tjedno i manje od jednom u dva tjedna, kao i potvrđivanje nezainteresiranosti za seksualne odnose.
Na tvrdnju „Smatram druge ljude seksualno poželjnima" najviše pozitivnih odgovora dobiveno je u skupini ispitanika koji u terapiji uzimaju SIPPS-e, a slijede oni koji uzimaju lijekove iz skupine SNRI.

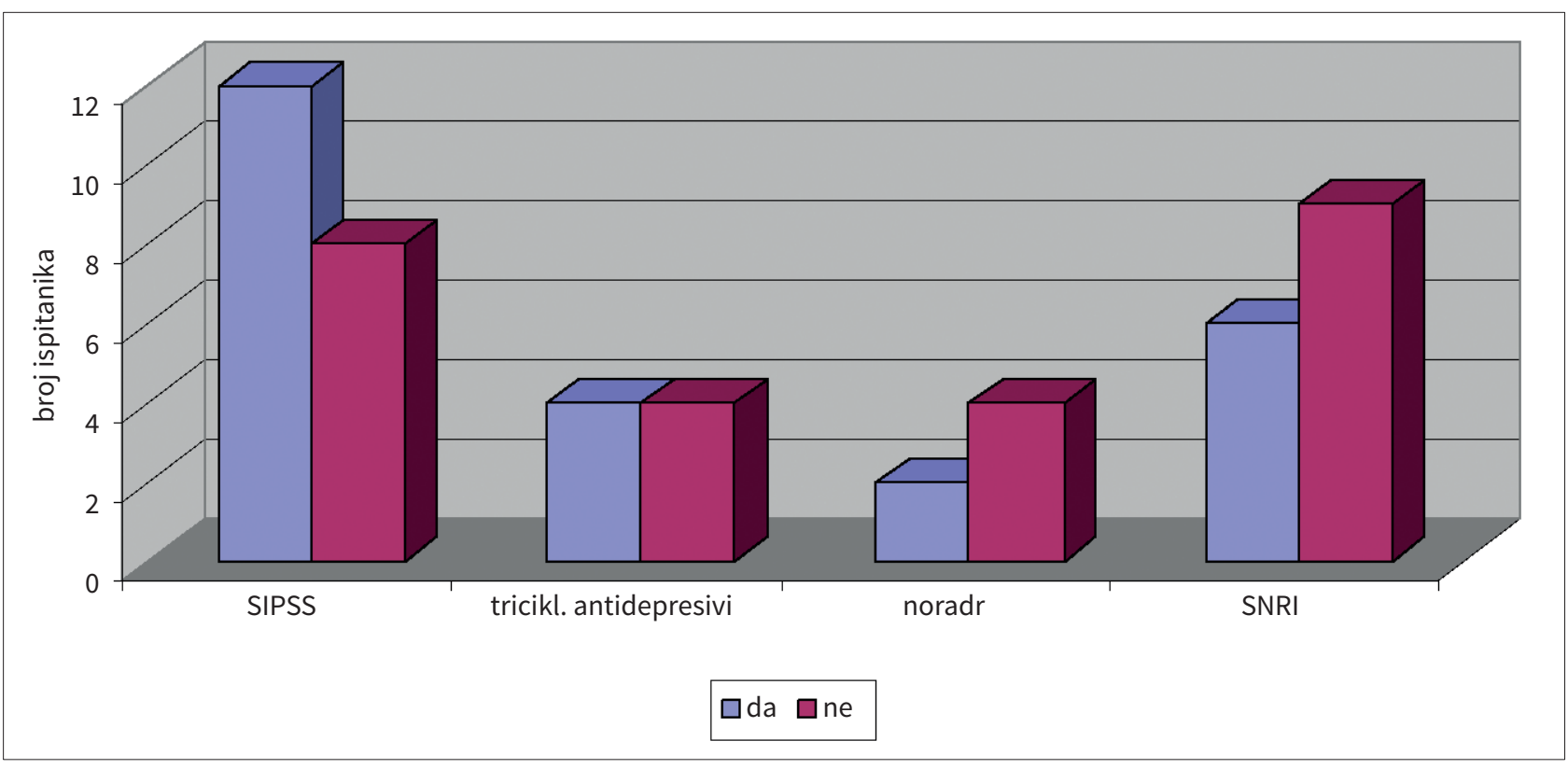

Slika 2. Odgovor bolesnika na tvrdnju „U zadnjih mjesec dana, iako sam bio/la mentalno uzbuđen/a, nije bilo fizičkih manifestacija" u odnosu na skupinu antidepresiva koji uzimaju

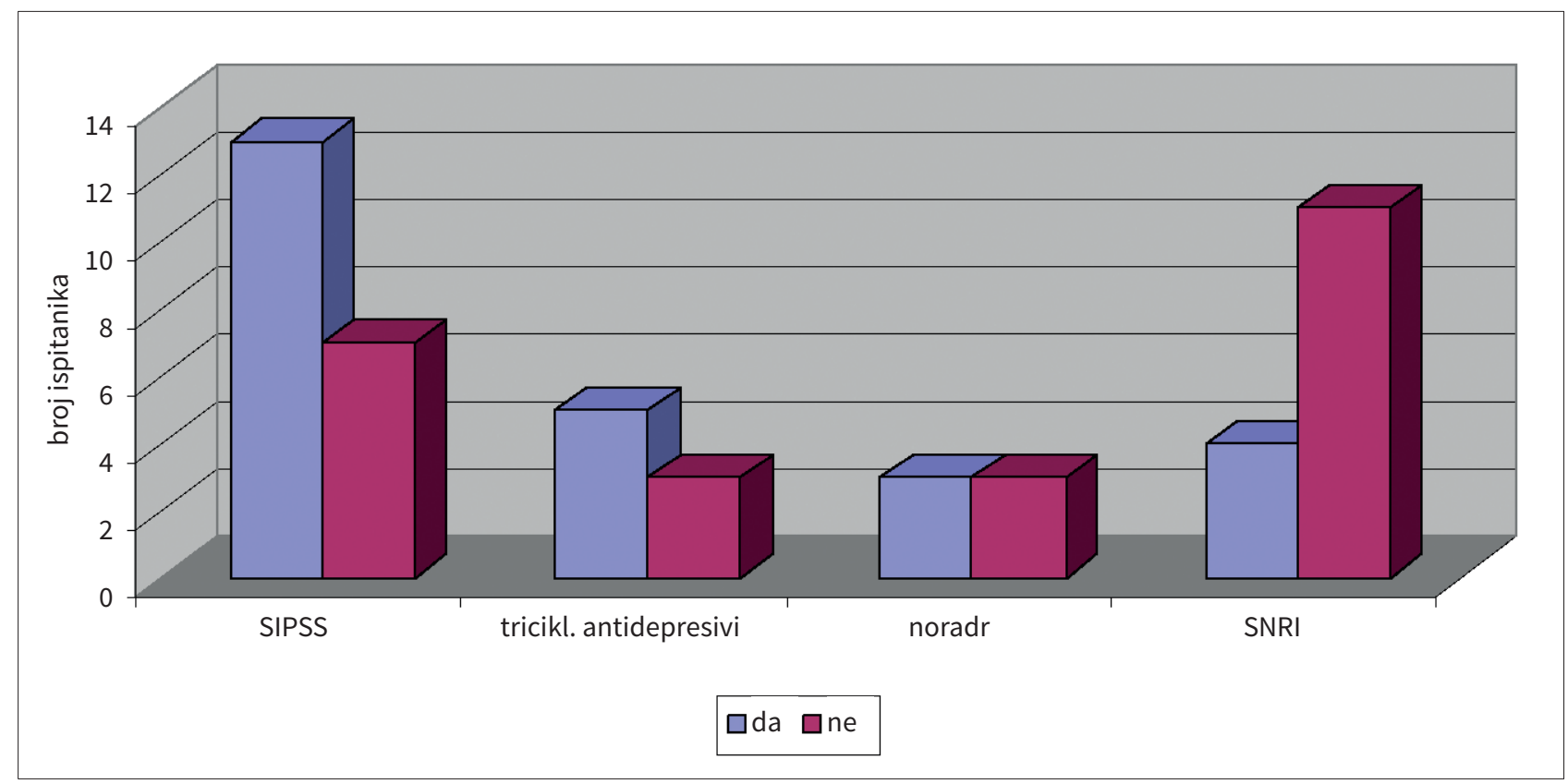

Slika 3. Odgovor bolesnika na tvrdnju "Nisam bio/la zainteresiran/a za seks" u odnosu na skupinu antidepresiva koji uzimaju 
Zadnjih mjesec dana u skupini bolesnika koji u terapiji uzimaju SIPPS-e najveći je broj onih koji su imali poremećaj seksualne želje, orgazma i poremećaj ejakulatorne funkcije.

\section{Rasprava}

Seksualna disfunkcija česta je nuspojava tretmana antidepresivima i glavni razlog za nesuradljivost u liječenju ${ }^{11}$.

Racionalna psihofarmakoterapija uključuje racionalne kombinacije lijekova koji imaju sinergistički terapijski učinak, smanjuju izraženost i broj nepoželjnih nuspojava, pokrivaju sve aspekte kliničke slike i dovode do brzog poboljšanja i zadovoljavajuće remisije ${ }^{3}$.

Za odabir prikladnog antidepresiva uz njegovu je učinkovitost važan i profil nuspojava koji utječe na primjenu lijeka i suradljivost bolesnika, što potvrđuju i rezultati brojnih istraživanja ${ }^{1,12,13}$.

Lijekovi sa serotonergičnom aktivnošću, kao što su SIPPS-i i venlafaksin, pridonose najvišoj stopi seksualne disfunkcije. Antidepresivi koji nisu iz skupine SIPPSa, kao što su duloksetin, reboksetin i mirtazapin, imaju manje seksualnih nuspojava nego lijekovi iz skupine SIPPS i venlafaksin. Agomelatin i bupropion slični su placebu s obzirom na seksualne nuspojave ${ }^{11}$. Tretman lijekovima SIPPS i SNRI povezan je sa seksualnom disfunkcijom. Upotreba drugih antidepresiva kao što je bupropion, mirtazapin, nefazodon i vilazodon povezana je s manje seksualnih disfunkcija u usporedbi sa SIPPS-ima. Nadalje, neki od spomenutih antidepresiva primjenjuju se u tretmanu seksualnih disfunkcija izazvanih lijekovima iz skupina SIPPS i SNRI ${ }^{14}$.

Većina antidepresiva izaziva negativne seksualne nuspojave, što vodi do nesuradljivosti u tretmanu. Znanja o međusobnoj vezi između depresije, antidepresiva i seksualnosti važna su s kliničkog stajališta ${ }^{15}$.

Prema rezultatima našeg istraživanja muški ispitanici koji u terapiji uzimaju antidepresive u zadnjih mjesec dana razmišlja o seksu tri puta tjedno statistički značajno češće nego što to čine žene.

Nema statistički značajnih razlika po spolu u tome jesu li se u zadnjih mjesec dana mogli seksualno uzbuditi, iako je razvidno da se muškarci češće lakše uzbuđuju od žena te da kod žena, iako su bile mentalno uzbuđene, češće nije bilo fizičkih manifestacija nego kod muškaraca.

U zadnjih mjesec dana muškarci su u $61 \%$ slučajeva uvijek mogli postići erekciju ako to žele, u 54 \% slučajeva im se čini da erekcije nisu potpune kao ranije, u $46 \%$ su slučajeva u zadnjih mjesec dana imali erekciju manje od jednom tjedno.

U žena su u zadnjih mjesec dana spolni odnosi bili otežani ili bolni zbog toga što nisu imale u potpunosti odgovarajuću tjelesnu reakciju, tjelesna reakcija na seksualnu stimulaciju sada je drugačija nego ranije i tjelesna reakcija na seksualnu stimulaciju sada je lošija nego ranije u više od $70 \%$ slučajeva.

Muškarci navode da su masturbirali manje od jednom u dva tjedna, što je statistički više nego što to navode žene. Statistički značajno više žena nikada ne masturbira u odnosu na muškarce.

Muškarci statistički značajno češće od žena dožive orgazam/ejakulaciju koliko god često žele. Kod žena je orgazam/ejakulacija bio statistički značajno drugačiji nego ranije u odnosu na muškarce. Muškarci statistički značajno češće doživljavaju orgazam/ejakulaciju pri svakom spolnom odnosu/masturbaciji u odnosu na žene.

U skupini ispitanika koji u terapiji uzimaju SIPPS-e najviše je i dobivenih odgovora o razmišljanjima o seksu manje od jednom tjedno i manje od jednom u dva tjedna, kao i potvrđivanje nezainteresiranosti za seksualne odnose (slika 1).

Na tvrdnju „Smatram druge ljude seksualno poželjnima" najviše pozitivnih odgovora dobiveno je u skupini ispitanika koji u terapiji uzimaju SIPPS-e, a slijede oni koji uzimaju lijekove iz skupine SNRI.

Zadnjih mjesec dana u skupini bolesnika koji u terapiji uzimaju SIPPS-e najveći je broj onih koji su imali poremećaj seksualne želje, orgazma, i poremećaj ejakulatorne funkcije.

Rezultati istraživanja ukazuju na to da se antidepresivi mogu podijeliti u kategoriju visokog rizika (selektivni inhibitori ponovne pohrane serotonina, inhibitori serotonin-noripinefrin pohrane, triciklički antidepresivi, inhibitori monoaminoksidaze) i niskog rizika (agomelatin, bupropion, moklobemid i reboksetin) s obzirom na sklonost za antidepresivima uzrokovanu seksualnu disfunkciju, ali postoje neslaganja posebno oko mirtazapina i metodološka pitanja u odnosu na krajnje rezultate. Prema rezultatima istraživanja Denta i sur., antidepresi- 
vima izazvana seksualna disfunkcija povezana je s dozom, ali bolesnikova vulnerabilnost također je važna ${ }^{13}$. Keks i suradnici upozoravaju na važnost upita bolesnicima koji uzimaju antidepresive u terapiji o seksualnim disfunkcijama, što može pridonijeti nesuradljivosti na liječenje antidepresivima ${ }^{17}$.

Čak do $70 \%$ bolesnika s depresijom može imati seksualnu disfunkciju koja može biti simptom osnovne bolesti ili pak nuspojava farmakoterapije antidepresivima ${ }^{1}$. Važno je razlikovati je li nuspojava nastala nakon što je uveden lijek ili se seksualna disfunkcija javila kada su se javili simptomi depresivnog poremećaja ${ }^{1}$.

Poznavanje profila nuspojava važno je zbog mogućeg utjecaja nuspojava na ishod liječenja te se zbog toga danas ističe važnost praćenja i ranog uočavanja nuspojava kod pacijenata tijekom liječenja. Nuspojave je važno što ranije prepoznati kako bi njihov štetni učinak bio umanjen, ali i stoga što mogu nepovoljno utjecati na suradljivost bolesnika u liječenju.

Nove spoznaje o biologiji depresije, farmakogenomici i neuroplastičnosti obećavaju razvoj novih antidepresiva s novim mehanizmima djelovanja, koji će biti još učinkovitiji i sigurniji, ali će ponuditi i produbiti spoznaje o biološkoj podlozi depresija, što će biti osnova za nove klasifikacije depresivnih i anksioznih poremećaja na principima strukturne validnosti ${ }^{10}$.

$\mathrm{U}$ radu prikazani ispitanici čine heterogenu skupinu $\mathrm{S}$ obzirom na to da uzimaju različite antidepresive te nisu kontrolirani za dob i duljinu trajanja uzimanja antidepresiva, što treba uzeti u obzir pri interpretaciji rezultata istraživanja.

Zaključno, rezultati ovog istraživanja pokazali su višu učestalost javljanja seksualnih disfunkcija u bolesnika s depresivnim poremećajem koji u terapiji uzimaju antidepresive iz skupine SIPPS, u usporedbi s pacijentima koji su uzimali antidepresive iz drugih skupina, što je u skladu s rezultatima iz literature. Rezultati istraživanja ukazuju na važnost redovitog praćenja seksualnih disfunkcija tijekom terapije antidepresivima u bolesnika s depresivnim poremećajem.

\section{Literatura}

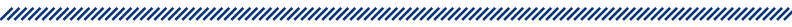

1. Uzun S, Kozumplik O, Mimica N, Folnegović-Šmalc V. Nuspojave psihofarmaka. Zagreb: Medicinska naklada; 2005.

2. Uzun S, Kozumplik O, Mimica N, Makarić G, FolnegovićŠmalc V. Nuspojave antidepresiva i interakcije s lijekovima iz drugih skupina. Medicus. 2004;13(1):69-75.

3. Dijagnostički i statistički priručnik za duševne poremećaje, četvrto izdanje (DSM-IV). Jastrebarsko: Naklada Slap; 1996.

4. Montejo AL, Lorca G, Izquierdo JA, Rico-Villade-Moros $F$. Incidence of sexual dysfunction associated with antidepressant agents: a prospective multicenter study of 1022 outpatients. Spanish Working Group for the study of Psychotropic-Related Sexual Dysfunction. Journal of Clinical Psychiatry. 2001; 62(Suppl 3):10-21.

5. Mimica N, Ivezić S, Uzun S, Kozumplik O, Lokas M, Folnegović-Šmalc V. Seksualne disfunkcije uzrokovane psihofarmacima. Medicina. 2005;42(41):310-316.

6. Ivezić S, Mimica N. Smjernice za dijagnosticiranje seksualnih poremećaja. Medicina. 2005;42(41):323-328.

7. Stevenson JM, Bishop JR. Genetic determinants of selective serotonin reuptake inhibitor related sexual dysfunction. Pharmacogenomics. 2014;15(14):1791-1806.

8. Clayton AH, El Haddad S, Iluonakhamhe JP, Ponce Martinez C, Schuck AE. Sexual dysfunction associated with major depressive disorder and antidepressant treatment. Expert Opinion on Drug Safety. 2014;13(10):1361-74.

9. Khazaie H, Rezaie L, Rezaei Payam N, Najafi F. Antidepressant-induced sexual dysfunction during treatment with fluoxetine, sertraline and trazodone; a randomized controlled trial. General Hospital Psychiatry. 2015;37(1):40-5.

10. Uzun S, Kozumplik O, Jakovljević M, Muck-Šeler D, Pivac N. Nuspojave antidepresiva. Medix. 2013;106:167-170.

11. Bergh SJ, Giraldi A. Sexual dysfunction associated with antidepressant agents. Ugeskrift for laeger. 2014;176(22):234236.

12. Janicak PG, Preskorn SH, Davis JM, Ayd FJ Jr. Principles and Practice of Psychopharmacotherapy. 3. izd. Chicago: Lippincott Williams and Wilkins; 2001.

13. Dent LA, Brown WC, Murney JD. Citalopram-induced priapism. Pharmacotherapy. 2002;22:538-541.

14. Clayton AH, Croft HA, Handiwala L. Antidepressants and sexual dysfunction: mechanisms and clinical implications. Postgraduate Medicine. 2014;126(2):91-99.

15. Porto R. Depressive symptoms and sexuality. Presse Médicale. 2014;43(10 Pt 1):1111-1115.

16. Keks NA, Hope J, Culhane C. Management of antidepressant-induced sexual dysfunction. Australasian Psychiatry. 2014;22(6):525-528. 


\section{FREQUENCY OF SEXUAL DYSFUNCTION IN PATIENTS WITH DEPRESSIVE DISORDER DIAGNOSIS TREATED WITH DIFFERENT CLASSES OF ANTIDEPRESSANTS}

1 Marijana Hodak Ivanišević

1 Suzana Uzun

1 Oliver Kozumplik

1,2 Ninoslav Mimica

1 University Psychiatric Hospital Vrapče, Bolnička cesta 32, 10090 Zagreb

2 Univesity of Zagreb, School of Medicine, Šalata 3B, 10000 Zagreb

\section{Abstract}

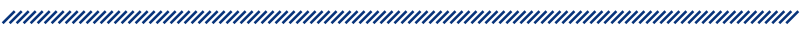

Aim: To analyze the frequency of sexual dysfunctions in patients with depressive disorder diagnosis treated with different classes of antidepressants

Subjects and methods: 50 patients with depressive disorder diagnosis who were either outpatients or inpatients at the Clinic for Psychiatry Vrapče, Department for Biological Psychiatry, participated in the investigation. Data were obtained from the conversation with the patients and from medical records. Sexual Function Scale was used in evaluation of sexual functioning of the participants. Prior to their involvement all participants were given the information about the research and they all signed an informed consent for their participation in the research. Differences between the observed values regarding sex and age categories were tested using the Fisher's Exact Test. The SPSS statistical program, version 13 (SPSS Inc, Chicago, IL, USA) was used in the analysis of the results. The results were interpreted with statistical significance of $\mathrm{P}<0,05$.
Results and conclusion: The results of this research showed higher frequency of sexual dysfunctions in patient with a depressive disorder treated with SSRIs in comparison with patients treated with other classes of antidepressants which is comparable with results from professional literature. The results point to the importance of regular monitoring of sexual dysfunctions during antidepressant treatment in patients with a depressive disorder.

Key words: antidepressants; depressive disorder; sexual side effects; treatment 